Trinity University

Digital Commons @ Trinity

Library Faculty Research

Coates Library

$2-2016$

\title{
Reflective Assessment: Opportunities and Challenges
}

Anne Jumonville Graf

TrinityUniversity, ajumonvi@trinity.edu

Benjamin R. Harris

Trinity University, bharris@trinity.edu

Follow this and additional works at: https://digitalcommons.trinity.edu/lib_faculty

Part of the Library and Information Science Commons

\section{Repository Citation}

Graf, A.J., \& Harris, B.R. (2016). Reflective assessment: Opportunities and challenges. Reference Services Review, 44(1), 38-47. doi: 10.1108/RSR-06-2015-0027

This Post-Print is brought to you for free and open access by the Coates Library at Digital Commons @ Trinity. It has been accepted for inclusion in Library Faculty Research by an authorized administrator of Digital Commons @ Trinity. For more information, please contact jcostanz@trinity.edu. 


\section{$\underline{\text { Reflective Assessment: Opportunities and Challenges }}$}

By Anne Jumonville Graf and Benjamin R. Harris

$\underline{\text { Abstract }}$

Purpose: Librarians engage in assessment for several purposes, such as to improve teaching and learning, or to report institutional value. In turn, these assessments shape our perspectives and priorities. How can we participate critically in the assessment of information literacy instruction and library programming while broadening our view and making room for questions about what we do? This paper explores self-reflection as a method for building on existing assessment practices with a critical consciousness.

Design/Methodology/Approach: In tracing the trajectory of assessment and reflective practice in library literature, the authors conducted a selective literature review and analyzed the potential impact of incorporating librarian self-reflection into assessment practices, particularly for instructional services. The authors' experiences with strategies informed by these conversations were also described.

Findings: Self-reflection has typically been employed to improve teaching or as a method of assessing student learning. However, it can also be used to develop a critical awareness of what we accomplish through the act of assessing. The authors develop and present self-reflective strategies and discuss their benefits and limitations.

Practical Implications: An extensive list of strategies was developed to illustrate practical examples of a reflective approach to assessment.

Originality/Value: Although librarians have used reflection as a type of assessment strategy, we have not viewed self-reflection as a method for evaluating other assessment techniques.

Librarians interested in exploring reflective practice and thinking critically about assessment will find strategies and suggestions for doing so.

\section{Introduction}

The assessment of information literacy instruction, learning, and programming more broadly has been a primary area of concern for librarians, before and well after the publication of the ACRL Competency Standards (see Brown and Niles, 2013; Hufford, 2013; Oakleaf, 2008; Pausch and Popp, 1997; Rockman, 2002; Samson, 2000; Smith, 2001; Tancheva et al., 2007; Walsh, 2009). We have faced challenges and seen successes in our efforts to find viable ways to assess information literacy teaching, learning, and development, and the Competency Standards 
were crucial to our professional conversations about assessment. At the same time, as we have incorporated ourselves into the cultures of assessment that have grown in our schools and universities, we may have become co-opted into assessment-driven-teaching strategies that encourage us to value assessment to a greater degree than we value the teaching and learning experience.

In 2015, with the shift toward the Framework for Information Literacy, we have openings for conversations that help us think again and anew about teaching and learning and the roles that assessment plays in these efforts. As Heidi Jacobs notes, “on a pragmatic level, we do need to evaluate how our programs and initiatives are working but we also consider the modes by which we judge or quantify our information literacy 'successes"” (2008, p. 257). Our aim in this article is to suggest methods for doing both, specifically, by considering the ways that reflective practice takes us from assessment focused on recording and reporting toward practices that ensure greater understanding about information literacy teaching and learning.

\section{Situating "Assessment"}

Professional conversations on the assessment of information literacy often focus on assessment tools and strategies, deliverable products, the uses of assessment data to portray the value of the library or institution. As a consequence, the word "assessment" may mean something different depending on the context or objective of the use. For many, "assessment" as an activity may reflect either formative or summative approaches. Formative assessment, focusing on the process of determining "what is happening" in the classroom during the teaching/learning situation, may involve quick surveys of students' comprehension or progress on a topic, note-taking on student activities during a session, or informal observations of student behavior and action during the class. Another active assessment technique, summative 
assessment, seeks to determine "what happened" in the classroom after the session has ended.

The forms of summative assessment may include authentic assessments such as the evaluation of student work, post-tests, and reflective narratives written either by students or instructors.

Assessment tools and strategies have received considerable focus in our professional discussions (Diller and Phelps, 2008; Gewirtz, 2014; Hufford, 2010; Hunt et al., 2000; Oakleaf and Kaske, 2009). The opportunity and need to collaborate with others, especially other teachers, suggests that ways that assessment methods can both utilize and also enhance relationships between librarians and other campus stakeholders (Brasley, 2008; Hoffman and LaBonte, 2012; Oakleaf et al., 2011). Ultimately though, as we can see in the words of many of these authors, the focus on practical assessment measures has not resulted in a "magic bullet" to gauge student or program success.

The term "assessment" is also used to identify deliverable products based on formative or summative assessments. Assessment in this case may refer to translating or aggregating observations and evaluations into digestible reports or data sets intended for specific audiences. Such reporting may often attempt to combine assessment data across instructors and classes to present a "bigger picture" of student learning as a consequence of information literacy instruction, the impact of information literacy programming, and its value to the local academic community and beyond. Deliverable assessment, more focused on offering evidence of value, may also reflect our fears that without some form of viable recording and reporting, teaching did not really "happen" and neither did learning.

"Assessment" then moves from a process or a product to an indicator of value, and may help to portray the impact of the library as well as the institution more broadly. As Elizabeth Mezick writes, “today's academic libraries are part of a team whose goal is to improve outcomes 
of organizational relevance such as student success and retention" (2015, p. 35). On the surface, a claim such as this has merit. The alignment between the library's or the information literacy instructor's definition of success with the organization's definition would then be key to operating effectively as a member of this team. But, what is this "success" that we continue to reference? Jacob's question about how we define "information literacy success" plays out at this level as well: how do we understand student success, or institutional success? The issue of audience — who the assessment is designed to inform — comes sharply into view. Assessment intended to help the instructor gauge the impact of their teaching on student development and ability might tell one story, while assessment intended to show the value of the library or its importance in the teaching mission of an institution may tell another. As the latter motivation has increased, it has affected the former.

In discussing the impact of the assessment-driven ACRL Standards on librarians' teaching, Emily Drabinski writes, "Such intervention [i.e., development and use of the Standards] was critical from the perspective of institutional resources: the Standards enabled us to make claims for resources. This past produced our present, one that has only intensified the demand for outcomes-based instruction, positivist approaches to learning assessment, and ongoing struggles to maintain a librarian voice in broader conversations about the future of higher education" (2014, p. 485). If that is true, can we participate in our own assessment-driven efforts while we also critically evaluate those efforts?

However, what if the problem with our use and understanding of assessment is not that it valorizes an assessment product over a teaching and learning process, but that it is still missing a crucial piece? Among the various uses of the term "assessment," we did not find a place for the instructor's reflective activity. Teacher self-reflection is often cast as a method of "teacher 
improvement" rather than as a viable assessment method, the products of which might be reported along with the quantitative and qualitative data we collect about student learning. Of course, the act of institutionalizing a role for reflection in assessment carries its own risks. Even the idea of a "reflective practitioner" can be neutralized and used to repress certain kinds of questions and veins of thought. Despite this risk, we can and should create formal space for reflection in instructional settings and as a form of assessment in order to re-integrate librarians, themselves, into our understanding of information literacy education. In particular, using reflection to re-imagine ways to think with and beyond learning outcomes can help revitalize our teaching as we move forward.

\section{Reflection in Librarianship}

While librarians have written about student reflection as a form of assessment (Farmer, 2004; Frey, 2011; Gilstrap and Dupree, 2008) discussions about potential benefits of reflective practice for librarians themselves are less common. Drawing on the literature of critical pedagogy, John Doherty stated frankly that "librarians are not very reflective practitioners" in part because our professional values of objectivity and neutrality inhibit critical self-reflection (2005, p. 12). How, exactly? Consider the current themes of library instructional practice, as described earlier, which focus largely on assessing student behavior and activity. As librarians, we are trained to inhabit an impartial and in some ways invisible role in the information seeking or information situation, to create an impartial distance where personal opinion or epistemology does not become a factor in the "user's" experience. Clearly, reflecting on student behaviors, activity, and learning is most assuredly useful; however, these factors should not suggest that the teacher must remove themselves from the teaching and learning situation or space during reflection. 
Since Doherty's claim about the lack of critical reflexivity in librarianship ten years ago, librarians have found more to say about our own reflective practices. In a 2007 review of the status of reflective practices in librarianship, Maria Grant found that published reflective accounts by librarians have grown more analytical over the last 25 years, away from earlier models of reflection as "retrospective accounts of careers and organizational development lacking insight into how experiences changed, influenced or informed future practice" (p. 164). Margaret Forrest (2008) introduced librarians to literature on critical reflective practice and reviewed several strategies for and benefits of reflective writing. In the realm of library instruction specifically, Mandi Goodsett (2014) examined the importance of reflection in teacher development and noted examples of teacher-librarians engaged in reflective strategies such as journaling, peer feedback, and video recording.

In a turn toward a more critical stance, Heidi Jacobs constitutes reflection as a cornerstone of pedagogy, suggesting that we develop our ability to "read" our own pedagogical practices through dialogue with students but also by questioning ourselves: "pedagogical reflection means that that we ask questions...of ourselves and our teaching and that we think critically and creatively about the small and large pedagogical choices we make." For Jacobs, "the question of how to go about enacting this creative, reflective dialogue is undeniably pressing" (2008, p. 262). Char Booth in part answers this call in Reflective Teaching, Effective Learning, in which "reflective practice is an attitude of constructive self-awareness" (2011, p. 151). Booth locates reflection and reflective self-questioning in instructional practice as a part of an ongoing assessment and learning process that values teacher learning as well as student learning (2011, p. 19). This move — to value teacher learning as well as student learning —is critical to the kind of reflective practice that can inform conversations about assessment as well. 
Finally, Michelle Reale's "Critical Pedagogy in the Classroom: Library Instruction that Gives Voice to Students and Builds a Community of Scholars" (2012) provides an inspiring picture of a critical pedagogy practitioner who uses reflection to question and challenge herself as well as her students, and who claims and shapes a role for herself in her instructional context.

We can extend the possibility of critical self-reflection in librarianship by looking at the work of Donald Schon, and specifically his work on reflective practice in professional contexts. For Schon, "when we set the problem [upon which we reflect and act], we select what we will treat as the 'things' of the situation, we set the boundaries of our attention to it" (1983, p. 40). In setting these boundaries, we are able to act and deal with the challenges that arise within those boundaries; however, as Schon cautions, over time we stop attending to the intellectual task of problem setting or identifying what is worth paying attention in the first place. This is not to minimize the importance of reflection as an approach to problem solving. Instead, it is a call to re-emphasize the process of framing and setting the problem in the first place. It is this step that can be so helpful in conversations about assessment practices. Schon highlights the consequences of skipping this step:

If [the practitioner] learns, as often happens, to be selectively inattentive to phenomena that do not fit the categories of his knowing-in-action [i.e., practical knowledge], then he may suffer from boredom and 'burn-out' and afflict his clients with the consequences of his narrowness and rigidity. When this happens, the practitioner has 'over-learned' what he knows.

A practitioner's reflection can serve as a corrective to over-learning. Through reflection, he can surface and criticize tacit understandings that have grown up around the repetitive experiences of a specialized practice... (1983, p. 61). 
It is not hard to imagine that the practitioner Schon describes could easily be an information literacy instructor, teaching similar sessions over and over again according to a set instructional mode. What kind of reflection could refresh that person's teaching practice? One option may be to first identify what has been 'over-learned,' and then to consider strategies for disrupting this routinized situation. The learning outcomes we most commonly assess may be useful starting points for examination and areas where we can learn the most about our own tacit understandings. This does not mean those outcomes and understandings are necessarily wrong or misguided, only that we are more likely to ignore information that could challenge our understanding of their importance.

Clearly, reflective practice has its benefits. Why, then, have librarians been slower to adopt this practice either individually or as a part of their assessment efforts? We see two likely reasons. First, reflective practice may be characterized by some as being either overly timeconsuming for professionals whose workloads are already substantial. Further, the benefits to the group or the institution may not be clear in the same manner as other assessment methods. The challenge, then, is to find strategies for reflective assessment that are feasible and productive while still allowing the potential for deep, robust thinking and understanding.

\section{Reflective Assessments: Two Strategies in Practice}

To further explore the connections that could be made between reflective practice and assessment methods, we experimented with two strategies for guided group reflection. Beyond the possible benefits of integrating reflections with our assessment efforts, we were also interested in the ways that reflective practice could be guided (particularly for professionals with limited experience as reflective practitioners) and group-oriented (to increase the feasibility of 
reporting the results of the effort). This resulted in strategies that had multiple benefits, and helped us to set aside preconceptions of reflective practice as a solitary activity with little outward benefit beyond the individual professional's development. Our experience also confirms the advice of Linda Valli, who has researched reflective practice among teachers. Valli notes that "because reflection is not an end in itself, but for the purpose of action, communal dialogue is essential" (2009, p. 86). For all its introspective connotations, self-reflection cannot be individually determined and realized; it is transformative through engagement.

\section{Strategy One: Unintended Outcomes}

Outcomes-focused teaching and assessment has its champions and its detractors, and for good reason. Learning outcomes lend themselves well to measurement of impact but have also been criticized for dictating behavior and learning of students at the expense of empowering them (Bennett and Brady, 2012). In other words, while learning outcomes clearly help the instructor plan a session around what he or she would like to see students doing, they may also limit what students can achieve or experience. Still, creating and reporting intended information literacy learning outcomes is a common practice in our library as in many others. Rather than dismantle the practice, we built on it by including a moment of reflection in the instruction reporting process. We asked teaching librarians not only to report the learning outcomes of their instruction sessions but also the unintended outcomes of the session. Unintended outcomes, most likely guided by student need or interest, can assist in removing the limitations or power structure by which the teacher sets goals for students to meet.

In our case, we allowed the reporting of unintended outcomes to remain voluntary and, as a result, instructors reported on the development of unintended outcomes for $30 \%$ of the instruction sessions held during the period of the experiment. Not all of the unintended outcomes 
were surprising; some may have been reasonably included as part of the plan for a session but were set aside in favor of other learning outcomes. However, during the session, it became clear that the learning outcome was necessary to achieve other goals. While not evidenced in our experiment, it is also likely that conversations could arise related to course or assignment issues, or on topics that are not seemingly relevant to the session if librarians were given some ideas about framing such conversations in outcome language. This strategy could also help librarians explore outcomes that are less easily assessed by conventional or quantifiable methods.

However, the fact that we did not see evidence of this practice at the individual level reinforces the importance of collective reflection as a second step, in which listening and responding to others' experiences may help us recognize tacit knowledge of our own practices.

Even with these opportunities to improve our strategy for eliciting unintended outcomes, pausing in the moment of "reporting" allowed librarians to engage in the kind of reflection that interested Schon as a possible corrective to "over-learning." Instead of only examining the results of set outcomes, which may be well-worn, librarians were compelled to examine what happened in the class beyond previously-conceived boundaries. Ultimately, this kind of analysis can be included in group discussions about "what we do" when we are teaching in the information literacy classroom, and broaden our perspectives about what we can do. Finally, such a strategy may help us to enhance our resilience during the teaching and learning moment as we adapt to the changing in-the-moment needs of a group of learners.

\section{Strategy Two: Guided Group Reflection}

When learning outcomes focus our attention solely on student behavior and student activity, there is little room to reflect on teacher experience. It falls outside the bounds of our attention, to use Schon's language (1983, p. 40). We wanted to know more about how librarians 
at our institution experience their own positionality in the classroom as teachers. We thought a more concrete, though admittedly narrower, entry into that conversation might be to reflect on the role of risk-taking in teaching. We developed a set of reflective prompts for our library instruction colleagues and asked them if they would be willing to participate in our experiment (see Appendix I). After agreeing, participants received an email with a series of questions about risk in teaching and learning. They were asked to respond to these questions based on a very recent and specific teaching situation, which we timed by consulting our group teaching schedule and sending the survey to an individual instructor just after they finished teaching.

Toward the end of the semester, we met to talk more about the resulting reflections and the framing of the experiment itself. Our discussion began with the different definitions we each ascribed to the term "risk" - specifically as it related to teaching and learning. In relating practices that felt "risky" in some way, our colleagues described two main modes: risks in speaking and risks in acting. For example, participants discussed the risk of asking students doing something unfamiliar, such as finding a book in the stacks when they had never done that before; this felt like a risk to both the student and the instructor, as not finding the book or finding the experience off-putting may not have been the desired outcome. Other decisions, such as basing a whole instruction session around student-generated questions and answers, felt risky for reasons familiar to any instructor: important topics may not come up, the librarian might not have known how to respond to particular questions, etc.

After working through individual definitions of "risk," the conversation shifted to the role of power dynamics in library instruction contexts, as risk-taking requires vulnerability. We talked frankly about how our roles and relationships to the course instructor impact our ability to take risks that compromised our role as an authority. Do we think of ourselves as "guest 
teachers" or "guest learners" in another instructor's space? What is challenging about conceding power and adopting a "guest learner" status? We did not conclude with answers about specific steps to take next or advice on how to be "better" guest learners or guest teachers in some abstract, generalizable way; however, we did come together in a discussion about our awareness of power, authority, and the complexity of the guest/host dynamic in a one-shot instruction session, enhanced through collective reflection. While the results of the experiment for each participant were different, this collaborative experience enhanced our mindful attention to risk taking in the classroom as individuals and as a group.

\section{Conclusions and Suggestions for Future Practice}

Our experiments resulted in continuing conversations and explorations of the ways that reflective practice can influence the ways we think about assessment practices as well as assessment reporting — an encouraging result. Our "unintended outcomes" strategy allowed us to piggy-back on the mechanism of an existing assessment structure (reporting and collecting learning outcomes for classes), but to find ways to question it as well. The survey and discussion about a particular aspect of reflective practice-librarian status and risk-taking in the classroom — resulted in a lively discussion but did not tie in directly to existing organizational or programmatic assessments. Still, these experiments informed the way we were thinking about teaching, learning, and assessment as we moved forward into future situations.

We realize, of course, that there are many more strategies that might help us to better understand the connections possible between reflective practice and our assessment efforts. To that end, we have generated a list of starting points, in addition to our own examples, that may be useful for others in practicing collective, self-reflective assessment: 
- Use student reflection techniques as launching points for self-reflection.

Many of us are familiar with "muddiest point" or "one-minute paper" assessments. What would happen if we asked ourselves to complete the same assessments of our teaching that we asked of students? What would we make of our own "muddiest points" when compared with student reflections?

- Use standards-based or quantitative assessments as launching points for self-reflection. This strategy may seem obvious but how often do we really think and explore the results of preand post-assessments or evaluations of students' work? Do we enhance those assessments with reflections on activities we observed or questions that arose in class? Or, do the statistics become the truth of the learning experience?

- Develop reflective practice partners outside the library.

There may be others on campus in different departments or units who are interested in selfreflective practice. Cross-departmental communication may help participants understand how others/departments use or view reflective assessments. This offers a pan-disciplinary perspective on reflective assessments in practice and reporting.

- Call out classroom omissions.

We may not often reflect on the topics, strategies, or issues that we did not broach with a particular class. Was there an opportunity to introduce or address a particular issue and you either intentionally chose to forego the discussion or didn't realize how/where it might have been relevant? Especially if there was a moment to confront an uncomfortable topic, it may be easier to avoid such "failures." However, reflecting on such moments can help us learn for the future. Too, this method could easily become a shared practice (back and forth over email with a partner, or in a group conversation, etc.). 
What all of these strategies have in common is a form of reflection-as-assessment that values questioning and interrogating past assumptions. We participate in assessment but we also seek creative ways to extend or complement it. Instead of viewing assessment methods as merely mechanisms for producing required "proof of value," the process of adding a reflective layer to assessment can help us more carefully evaluate what it is we profess to value in the first place.

\section{Appendix I: Survey for guided group reflection}

Directions: Please answer the following questions as soon as possible after your instruction session.

bell hooks (1994) contends that teacher empowerment "cannot happen if we refuse to be vulnerable while encouraging students to take risks."

1. What risks did you encourage students to take in today's instruction session?

2. What risks did you embrace, yourself, in today's instruction session?

3. If you were asked to "take a risk" when teaching this class again, what might you do?

4. Having considered these questions, do you have anything you would like to add? 


\section{References}

Association of College and Research Libraries (2000), Information Literacy Competency

Standards for Higher Education, American Library Association, available from:

http://www.ala.org/acrl/standards/informationliteracycompetency (accessed 26 June 2014).

Association of College and Research Libraries (2015), Framework for Information Literacy for

Higher Education, available from: http://www.ala.org/acrl/standards/ilframework (accessed

8 June 2015).

Bennett, M. and Brady, J. (2012), "A radical critique of the learning outcomes assessment movement", Radical Teacher, No. 34, pp. 34-47.

Booth, C. (2011), Reflective Teaching, Effective Learning: Instructional Literacy for Library 
Educators, American Library Association, Chicago, IL.

Brasley, S. (2008), "Effective librarian and discipline faculty collaboration models for integrating information literacy into the fabric of an academic institution", $\mathrm{New}$ Directions for Teaching \& Learning, Vol. 2008, No. 114, pp. 71-88.

Brown, R. and Niles, P. (2013), “Assessment of information literacy: A critical bibliography”, Codex Vol. 2, No. 3, pp. 100-149.

Diller, K.R. and Phelps, S. F. (2007), "Learning outcomes, portfolios, and rubrics, oh my! Authentic assessment of an information literacy program", portal: Libraries and the Academy, Vol. 8, No. 1, pp. 75-89.

Doherty, J. (2005), "Towards self-reflection in librarianship: What is praxis?", Progressive Librarian, No. 26, pp. 11-17.

Drabinski, E. (2014), “Toward a Kairos of Library Instruction”, The Journal of Academic Librarianship, Vol. 40, No. 5, pp.480-485.

Farmer, L. (2004), "Narrative inquiry as assessment tool: A course case study," Journal of Education for Library \& Information Science, Vol. 45, No. 4, pp. 340-351.

Forrest, M. (2008), “On becoming a critically reflective practitioner,” Health Information \& Libraries Journal, Vol. 25, No. 3, pp. 229-232.

Frey, S. (2011), "Facilitating critical thinking and self-reflection: Instructional strategies for strengthening students' online research skills," Indiana Libraries, Vol. 30, No. 1, pp. 4956.

Gewirtz, S. R. (2014), "Evaluating an instruction program with various assessment measures", Reference Services Review, Vol. 42, No. 1, pp.16-33.

Gilstrap, D., and Dupree, J. (2008), “Assessing learning, critical reflection, and quality 
educational outcomes: The critical incident questionnaire," College \& Research Libraries, Vol. 69, No. 5, pp. 407-426.

Goodsett, M. (2014), "Reflective teaching: Improving library instruction through self-reflection", Southeastern Librarian, Vol. 62, No. 3, pp. 12-15.

Grant, M.J. (2007), "The role of reflection in the library and information sector: a systematic review", Health Information \& Libraries Journal, Vol. 24, No. 3, pp. 155-166.

Hoffman, D. and LaBonte, K. (2012), "Meeting information literacy outcomes: Partnering with Faculty to create effective information literacy assessment", Journal of Information Literacy, Vol. 6 No. 2, pp. 70-85.

hooks, b. (1994), Teaching to Transgress: Education as the Practice of Freedom, Routledge, New York, NY.

Hufford, J.R. (2010), "What are they learning? Pre- and post-assessment surveys for LIBR 1100, Introduction to Library Research", College \& Research Libraries, Vol. 71, No. 2, pp. $139-158$.

Hufford, J.R. (2013), “A review of the literature on assessment in academic and research libraries, 2005 to August 2011", portal: Libraries and the Academy, Vol. 13, No. 1, pp. $5-35$.

Hunt, S.K. et al. (2000), "Using student portfolios as authentic assessment of the basic communication course", Journal of Excellence in College Teaching Vol. 11, No. 1, pp.57-77.

Jacobs, H.L.M. (2008), “Information literacy and reflective pedagogical praxis", Journal of Academic Librarianship, Vol. 34, No. 3, pp. 256-262.

Mezick, E. M. (2015), "Relationship of library assessment to student retention", Journal of 
Academic Librarianship, Vol. 41, No. 1, pp. 31-36.

Oakleaf, M.J. (2008), “Dangers and opportunities: A conceptual map of information literacy assessment approaches", portal: Libraries and the Academy, Vol. 8, No. 3, pp. 233-253.

Oakleaf, M.J. and Kaske, N. K. (2009), "Guiding questions for assessing information literacy in higher education", portal: Libraries and the Academy, Vol. 9, No. 2, pp. 273-286.

Oakleaf, M. et al. (2011), “All together now: Getting faculty, administrators, and staff engaged in information literacy assessment", portal: Libraries and the Academy, Vol. 11, No. 3, pp. 831-852.

Pausch, L.M. and Popp, M.P. (1997), “Assessment of information literacy: Lessons from the higher education assessment movement", paper presented at the Association of College and Research Libraries National Conference (ACRL), Nashville, TN, available at http://www.ala.org/acrl/publications/whitepapers/nashville/pauschpopp.html (accessed 6 June 2015).

Reale, M. (2012), "Critical pedagogy in the classroom: Library instruction that gives voice to students and builds a community of scholars", Journal of Library Innovation Vol. 3, No. 2, pp. 80-88.

Rockman, I. F. (2002), "Strengthening connections between information literacy, general education, and assessment efforts", Library Trends, Vol. 51 No. 2, pp. 185-198.

Samson, S. (2000), "What and when do they know? Web-based assessment", Reference Services Review, Vol. 28, No. 4, pp. 335-342.

Schon, D. (1983), The Reflective Practitioner, Basic Books, New York, NY.

Smith, L. (2013), "Critical information literacy instruction for the development of political agency", Journal of Information Literacy Vol. 7, No. 2, pp. 15-32. 
Tancheva, K. et al. (2007), "Library instruction assessment in academic libraries", Public Services Quarterly, Vol. 3 No. 1-2, pp. 29-56.

Valli, L. (1997), "Listening to other voices: A description of teacher reflection in the United States”, Peabody Journal of Education, Vol. 72, No. 1, pp. 67-88.

Walsh, A. (2009), “Information literacy assessment: Where do we start?”, Journal of Librarianship and Information Science, Vol. 41, No. 1, pp. 19-28. 